レーザーノート 2

\title{
放電管励起色素レーザーの製作技術
}

\section{前田三男 ${ }^{*}$. 宮副 泰** \\ Techniques for Construction of Flashlamp-pumped Dye Lasers}

\author{
Mitsuo MAEDA* and Yasushi MIYAZOE**
}

\section{1 、まえがき}

1966年にSorokinらにより色素レーザーの最 初の実験が行なわれて以来，ここ教年間の色素 レーザーの発達は目党しく, 可変波長レーザー として確立した地位を占めるに至っている。ま た実用的な装置の開発や製品化が進むにつれ, 分光学等への応用研究が盛んになりつつあり, いろいろな分野で，色素レーザーを研究に使い たいという声を耳にするようになった。色素し ーザー一般に関する解説は他にあるので, ${ }^{1-3)} こ$ こでは色素レーザーを研究用に試作しようとす る方々のために，筆者の経験に基いて放電管励 起色素レーザーの設計・製作の実際的な方法を 述べる。

一般に光ポンピングが用いられる色素レーザ 一は, 励起光源の違いによりレーザー励起形と 放電管励起形とに分けられる。レーザー励起形 では，CW発振ができるアルゴンレーザー励起 や，広い波長域でくり返しの早い発振ができる 窒素パルスレーザー励起等が実用的に重要であ る。それに対して放電管励起の特長は(1)パルス 当りの出力エネルギーが大きいこと, (2) 装置が 比較的安価にできること，(3) 白色光であるため に発振波長域に対する本質的な制限がないこと 等があげられる。

本稿では試作例として, 最大出力 $180 \mathrm{~mJ}$ の直 線形放電管励起色素レーザーをとり上げる。試 作機の特性をまとめると Table 1 の通りである。 その外観を Fig. 1 に示す。
Table 1. Specification and performance of the constructed dye laser

$\begin{array}{ll}\begin{array}{l}\text { Maximum out energy } \\ \text { Tuning range }\end{array} & \begin{array}{l}180 \mathrm{~mJ} \text { (at 145 J input, } 597 \mathrm{~nm}) \\ 455 \sim 485,515 \sim 695 \mathrm{~nm} \\ \text { (tuning with a grating) }\end{array} \\ \text { Pumping source } & \begin{array}{l}\text { A linear flashlamp with } \\ \text { elliptical cavity }\end{array} \\ \text { Condenser } & 1 \mu \mathrm{F} 20 \mathrm{kVDC}(200 \mathrm{~J} \max ) \\ \text { Waveform of pumping } & \text { Risetime } 1 \mu \mathrm{s}, \mathrm{FWHM} 3.6 \mu \mathrm{s} \\ \text { light } & 5 \mathrm{~mm} \text { inner dia., } 130 \mathrm{~mm} \text { gap } \\ \text { Flashlamp } & \text { length (forced air cooling) } \\ \text { Dye cell } & 5 \mathrm{~mm} \text { inner dia., 180 mm overall } \\ \text { length (solution is circulated) } & 12 \mathrm{ppm} \text { (air cooling) } \\ \text { Repetition rate } & 3 \sim 10 \mathrm{mrad} \text { (untuned case) } \\ \text { Beam divergence } & \end{array}$

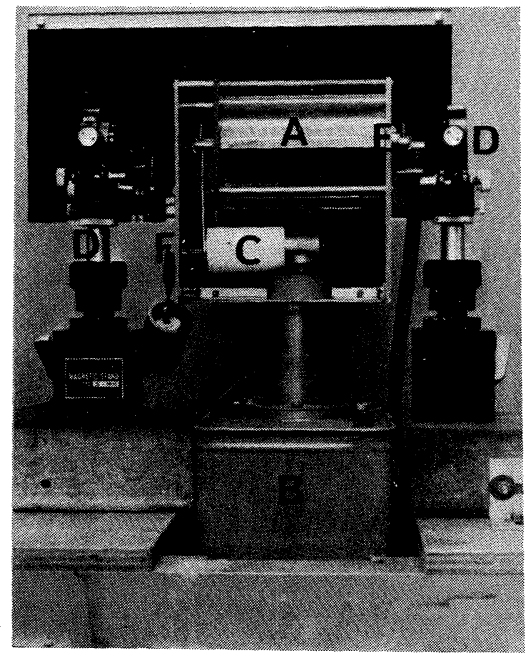

Fig. 1. A photography of the dye laser system.
A: Elliptical reflector, B: Condenser,
C: Triggered spark gap, D: Cavity mirror, E: Dye cell, F: Trigger terminal.

* **九州大学工学部 電気工学科

* ** Department of Electrical Engineering, Kyushu University, Hakozaki, Fukuoka 


\section{2.コンデンサおよび放電回路}

色素レーザーではルビーレーザー等と異なり， 通常 $10^{-7} \sim 10^{-6}$ 秒の早い励起立上り時間に設計 される。この理由は色素の励起状態の寿命が短 い $(\mathrm{ns}$ オーダ $)$ とと, 三重項状態への分子の蓄 積による発振の抑制を避けるためである。”放電 管励起の場合 10 ～ $100 \mu \mathrm{s}$ の遅い立上りでも，三 重項消光剤を使えば発振は可能であるが, 効率 が悪い上に熱ひずみのために発振時間を $10 \mu \mathrm{s}$ 以 上継続させることは容易でない。逆に立上り時 間を100ns以下にすれば，発振可能域が紫外か ら近赤外まで拡がる等，著しい特性の改善が見 られることを筆者は先に報告した。”

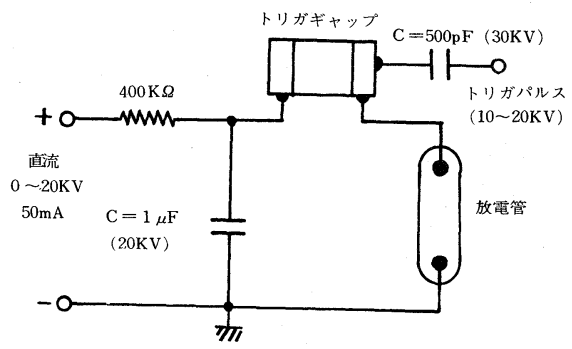

Fig. 2. Electrical circuit of flashlamp system.

Fig. 2に放電回路を示す。放電回路をコンデン サC，回路の残留インダクタンス Lおよび放電 抵抗 R $(0.1 \sim 1 \Omega$ オーダ) の直列回路と兒なす と,そのリンギング周波数は,

$$
\nu=\frac{1}{2 \pi}\left(\frac{1}{\mathrm{LC}}-\frac{\mathrm{R}^{2}}{4 \mathrm{~L}^{2}}\right)^{\frac{1}{2}}
$$

となるから，立上りを早めるにはL，Cを小さ くすればよい。そのため同一エネルギーを得る には，絶緣に支障のない範囲で電圧を高めCを 小さく設計した方が有利である。Lはコンデン サの内部残留インダクタンスとリード線や放電 管部のインダクタンスよりなる。インダクタン スを減らすには回路を太くつくり，局部的に強 い磁界ができるのを避けることが大事である。 試作機では $\mathrm{C}=1 \mu \mathrm{F}$ とし, $\mathrm{L}=0.1 \mu \mathrm{H}$ 以下の低 残留インダクタンス形コンデンサを特註し（二 コチン OBSI-H $20 \mathrm{CHW}$ ), 『ig. 10ごとくレ 一ザーヘッドをその上にのせて放電回路を極力
短くすることにより,Fig. 3に亦すように市にり $1 \mu \mathrm{s}$ を得た。リンギング周波数より逝算すると 回路の L は $0.23 \mu \mathrm{H}$ であった。

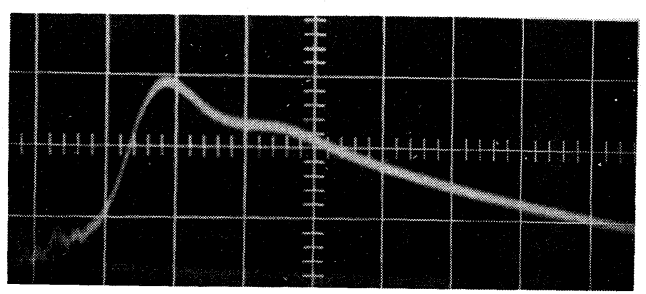

Fig. 3. Waveform of pumping light. Sweep: $1 \mu \mathrm{s} /$ div., air 30 torr, $128 \mathrm{~J}$ input energy.

\section{3. 放電管およびトリガギャップ}

色素レーザーに使われる放電管には同軸形 ${ }^{1}$ と直線形とがある。前者は放電回路のインダク タンスが小さくできるために立上りの早い励起 を行う際に有利であるが，放電管を取換えると き色素セルも含めて交換せねばならないこと， 放電時におけるセルとの音響的・熱的結合のし や断が困難であること等が欠点としてあげられ る。

直線形放電管の場合には，従来からある固体 レーザー用キセノン管を使うことも可能である が，色素レーザーの場合には短時間に大電流の 放電を行うため, 放電のショックで破損しやす いようだ。最近では色素レーザー專用の放電管 も二三発売されている。破損の起こる臨界入力 エネルギーは放電管の内容積と放電パルス幅の $1 / 2$ 乗に比例して高くなることが知られてい るが, ${ }^{5)}$ 放電管を無暗に大きくつくることはレー ザー効率を著しく悪化させるので避けねばなら ない。管材の厚みを増すことはショックによる 破損を防ぐのに有効である。また Ferrar ${ }^{6)}$ は 放電管にショックアブゾーバをつけることによ り，小容積で破損エネルギーの高い放電管をつ くっている。

試作機ではFig.4(a)に示したような手製の放電 管を用いた。管材は内径 $5 \mathrm{~mm} \phi$, 外径 $9 \mathrm{~mm} \phi$ の肉厚石英管, 電極はタングステンである。入 力 $130 \mathrm{~J} て ゙ 3000$ 回以上の反復放電に耐える。放電 をくり返すと石英管内部に細い亀裂が生じ白ず 


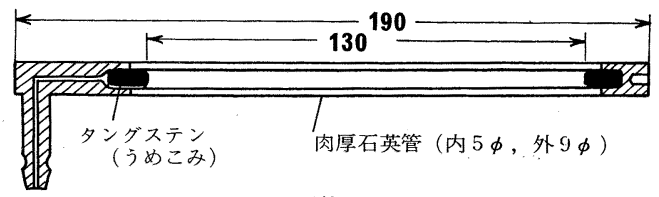

(a) 放電管

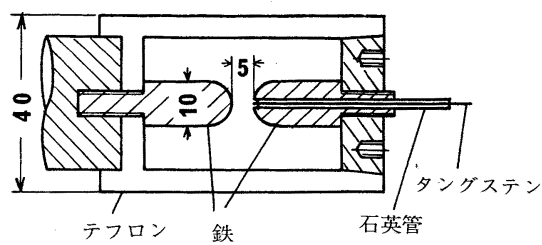

(b ) トリガギャップ

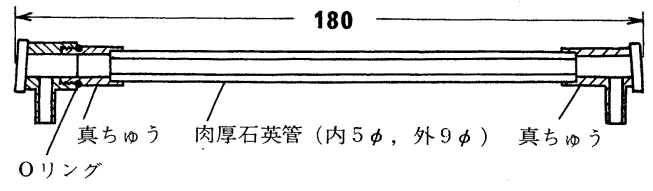

(c) 色素七ル

Fig. 4. The construction of flashlamp (a), triggered spark gap (b), and dye cell (c). Unit: $\mathrm{mm}$

んでくる。放電管の組立てにはエポキシ系接着 材を用い，ガスは封じ切らないで実験の度に真 空ポンプで入れ換えている。封入ガスはキセノ ン，アルゴン，空気の三種を試みたが，いずれ の場合にもレーザー出力に大きな差を見出せな かったので，主に空気を使用している。封入気 圧は10～50 Torr にわたって効率にあまり影響 はなかった。

放電光の色素七ルへの集光は楕円筒鏡を使っ た。楕円筒鏡は放電管の絶縁にさえ注意すれば, 一般の固体レーザー用のものと同じでよい。試 作機では銅板の一面を研磨後真空アルミメッキ して反射率を高めたものを，楕円に曲げて使っ ている。

トリガギャップはFig. 4(b)に使したような構造 で，常圧下ギャップ長約 $5 \mathrm{~mm}$ で放電する。7 $17 \mathrm{KV}$ でトリガ可能であった。電極は鉄材であ るが，数千回の放電によって囲りの絶縁物にス パッタし，トリガが不整になるので, 時々分解 して内面を清掃する必要があった。

\section{4. 色素セルおよび色素}

Fig. 4 (c)に色素セルを示す。セルの内径と外径
は放電管のそれに一致させた。セルの内径が大 きすぎると発振の臨界エネルギーが著しく上昇 するので，発振しにくい色素の場合には細目の セルの方が良い。セルはエポキシ系接着材では

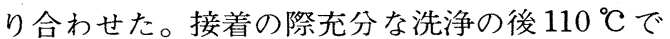
数時間の硬化を行なえば，アルコール類に対し ても実用上充分な耐久力をもたせることができ る。色素溶液は容量 $400 \mathrm{cc}$ のリザーバを通して 小形回転ポンプで毎秒 $15 \mathrm{cc}$ の割合で循環させて いる。液の温度上昇を防ぐため，リザーバをフ ァンで空冷している。

試作機で発振できる色素を各波長毎に Table 2に示す。485～515nmにある切れ目を除けば, 455 ～695nm の波長域で発振可能であった。色素と 溶媒は市販試薬級のものでもさしつかえないが, 純度を上げることによって特性が改善されるこ とが多い。例えば市販の Rhodamine 6 G とRhodamine B（いずれも東京化成製）を，酸を用 いて再結晶精製すると，レーザー出力がそれぞ れ 1.6 倍および 2 倍に増加した。単にろ過した だけでも効率が上ることがある。

色素溶液は光をあてなければ一年程度で劣化 が認められることはないが，レーザーに使用す ると劣化が認められる。Xanthine系色素の退色 は主に酸化反応と考えられ，反応は照射光量と 溶液中に溶け込んだ酸素の量に依存する。 ところ溶液の劣化を防ぐ決定的な方法はなく, 高い効率を維持するには時々新しい液に取換え る必要がある。

\section{5. 発振の諸特性}

本機の最大出力は，Rhodamine $6 \mathrm{G}$ を用い て $180 \mathrm{~mJ}$, 効率は $0.13 \%$ であった。その際の出 力鏡の反射率は $30 \%$ ，共振器長は $25 \mathrm{~cm}$ である。 最近の報告では最高効率 $1.2 \%,{ }^{9)}$ 最高出力 $32 \mathrm{~J}^{10)}$ が得られているが，出力を増加するには励起光 の「時間的・空間的密度」を高めることが最も 重要であり，色素レーザーにあってはいたずら に装置を大形化しただけでは出力が増加しない ことが多い。

Fig. 5 に10秒毎に連続200回の発振を行なった 
Table 2. Lasing dyes and their performances

\begin{tabular}{|c|c|c|c|c|}
\hline Dye (Supplier) & Solvent & Concentration & Output energy ${ }^{a}$ & Tuning range ${ }^{b}$ \\
\hline Cresyl Violet (Tokyo Kasei $)^{*}$ & Methanol & $3 \times 10^{-4} \mathrm{M}$ & $60 \mathrm{~m} \mathrm{~J}$ & $642 \sim 695 \mathrm{n} \mathrm{m}$ \\
\hline Rhodamine B (Tokyo Kasei)* & Ethanol & $1.5 \times 10^{-4}$ & 150 & $602 \sim 651$ \\
\hline Rhodamine 6 G(Tokyo Kasei)* & Ethanol & $1.5 \times 10^{-4}$ & 180 & $573 \sim 622$ \\
\hline $\begin{array}{c}\text { Brilliant Sulfoflavine } \\
\text { (Tokyo Kasei })^{*}\end{array}$ & $\begin{array}{l}\text { Ethanol } \\
+ \text { COT }^{c}\end{array}$ & $4 \times 10^{-4}$ & 13 & $515 \sim 583$ \\
\hline $\begin{array}{l}\text { 7-Diethylamino-4-methyl } \\
\text { coumarine (Dojindo) }\end{array}$ & Ethanol & $4 \times 10^{-4}$ & 31 & $455 \sim 485$ \\
\hline
\end{tabular}

* Purified in our laboratory.

a. $145 \mathrm{~J}$ input energy, $25 \mathrm{~cm}$ cavity length, $\mathrm{R} \fallingdotseq 30 \%$, untuned case.

b. Grating (1200 line/mm), $30 \mathrm{~cm}$ cavity lengty, $\mathrm{R} \doteqdot 70 \%$.

c. Added in the deoxygenated solution by bubbling of $\mathrm{N}_{2}$ gas.

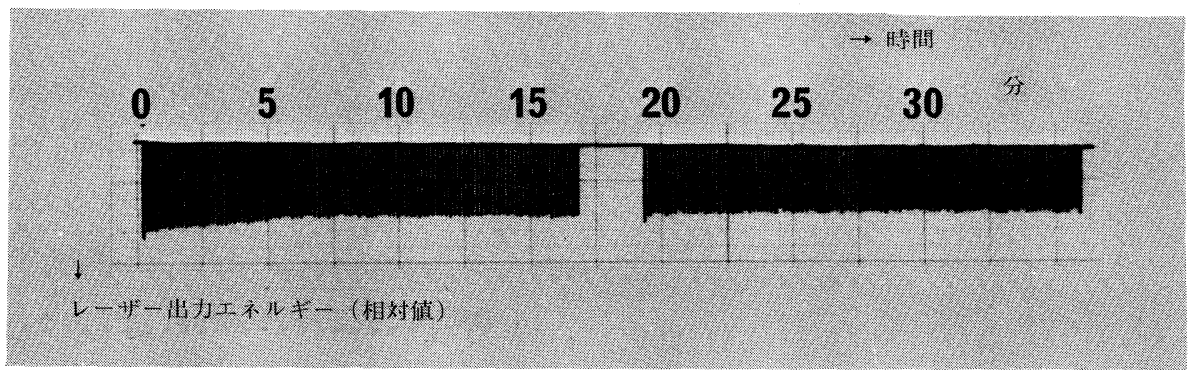

Fig. 5. The lasing output energy in the case of repetitive operation of $6 \mathrm{ppm}$. Rhodamine $6 \mathrm{G}, 130 \mathrm{~J}$ input energy, forced air cooling, total 200 shots (a rest for 150 second in the midst).

際の出力エネルギーの変化を示す。その際楕円 筒鏡内をポンプで排気空冷している。水冷式に すれば $1 \mathrm{~Hz}$ 以上のくり返しも可能と思われるが, 放電管の寿命を考えれば長時間の運転は無理で あろう。外国では最高 $100 \mathrm{~Hz}$ で $2.5 \mathrm{~W}$ の平均出 力が得られた報告がある。 ${ }^{11)}$

Table 2 に回折格子 (1200本/mm,ブレーズ波長 $500 \mathrm{~nm}$ ）を反射鏡の代わりに用いて波長を変え たときの tuning rangeを示した。出力を上げる と回折格子面を痛めるので, 出力の測定はして いない。スペクトル幅は弱い励起の場合 $3 \AA$ 程 度であった。本機の共振器内に三種のエタロン 板 (厚さ $1 \mathrm{~mm}, 0.15 \mathrm{~mm}, 0.01 \mathrm{~mm}$ )を挿入して, 最 小 $0.04 \AA 00$ のペクトル幅での発振が得られたこ とを，先に報告している。

また本機を用いて可飽和吸収体で自己モード 同期をかけると最小幅 $6 \mathrm{ps}$ のパルス列が得られ る。

\section{6. むすび}

筆者の経験をもとに，研究室的センスでの中 形放電管励起色素レーザーの製作法を述べた。 本試作機の原形は1968年に製作され ${ }^{14)}$ その後 1972年に改良されて現在まで安定した性能を維 持している。

最近外国では性能の良い色素レーザーがメー カから次々に発売されているのに対し, 我国は 大きな遅れをとってしまったような感じがしてな らない。メーカでなら，放電管にしろ，コンデ ンサにしろ，色素レーザーに適した部品を開発 してゆくことにより，ここに述べた試作機以上 のものを作ることは容易なように思われる。我 国においても，優れた色素レーザーが開発され ることを期待する。 


\section{参考交献}

1) P. P. Sorokin et al: J. Chem. Phys. 484726 (1968)

2) M. Bass et al : Lasers III (Mercel Dekker Inc. 1971) p. 269

3）前田，宮副：応用物理 41818 (1972)

4) M. Maeda, Y. Miyazoe: J. J. A. P. 11692 (1972)

5) ILC Technical Bulletin No. 5

6) C. M. Ferrar: Rev. Sci. Instr. 401436 (1969)

7) 筆者も最近類似の方法で出力 $1 \mathrm{~J}$ の高出力色素レ

ーザーを製作した。(unpublished)
8 ) 前田, 山本, 宮副：昭和47年電気四学会九州支部 連大 556

9) P. Anliker et al: Optics Comm. 5137 (1972)

10) V.A. Alekseek, I. V. Antonov: Soviet J. Quantum Elec. 1643 (1972)

11) W. Schmidt, N. Wittekindt: Appl. Phys. Letters 2071 (1972)

12）前田他：九州大工学集報 $46 \quad 371$ (1973)

13) 前田他：信学会量エレ研究会資料 QE 72-60（1972）

14）宮副, 前田：九大工学集報 41778 (1968) 